\title{
The Effect of COVID-19 Outbreak on Older Adults' Hopelessness, Loneliness and Spiritual Well-Being in Turkey
}

\author{
Mustafa Durmuş ${ }^{1}\left({ }^{1} \cdot\right.$ Zeynep Öztürk $^{2}$ (])
}

Accepted: 25 December 2021 / Published online: 7 January 2022

(c) The Author(s), under exclusive licence to Springer Science+Business Media, LLC, part of Springer Nature 2022

\begin{abstract}
The aim of this study was to determine the hopelessness, loneliness and spiritual well-being of older adults and the relationship between these three concepts during the COVID-19 pandemic. This research used a cross-sectional, descriptive approach. Data were collected between October 13 and November 13, 2020, with 476 individuals over 65 years living in three different cities in Turkey. Data were collected using a demographic information form, Beck Hopelessness Scale (BHS), Loneliness Scale (UCLA-LS) and Spiritual Well-being Scale (FACIT-Sp). During the COVID19 outbreak, it was found that there was a significant negative relationship between hopelessness, loneliness and spiritual well-being of older adults. In this study, it was found that during the COVID-19 pandemic, the level of hopelessness and loneliness among older adults was below the average score, and their spiritual well-being levels were moderate. Based on the findings of the present study, it is recommended that practices which increase hope, strengthen social ties and spiritual support, should be implemented for older individuals during the COVID-19 pandemic period or any other times during which social distancing is mandatory.
\end{abstract}

Keywords COVID-19 $\cdot$ Older adults $\cdot$ Hopelessness $\cdot$ Loneliness $\cdot$ Spirituality

\section{Introduction}

COVID-19 was first detected in Wuhan, China, at the end of 2019 and spread to the whole world, causing a pandemic. More than 31 million people have been infected so far and approximately 900,000 people have died (World Health Organization, 2020).

Mustafa Durmuş

saremeryem01@gmail.com

1 Department of Gerontology, Faculty of Health Sciences, Mus Alparslan University, 49100 Muş, Turkey

2 Department of Psychiatric Nursing, Faculty of Nursing, Ataturk University, 25240 Erzurum, Turkey 
Studies have shown that the COVID-19 outbreak has the most serious consequences, especially for the older adult population (Lian et al., 2020; Liu et al., 2020; Niu et al. Niu, Jia, et al., 2020, Niu, Tian, et al., 2020). It has been reported that the virus causes higher mortality rates, especially in older adults compared to other age groups (Niu et al. Niu, Jia, et al., 2020, Niu, Tian, et al., 2020).

As in many countries, Turkey's government has also implemented nationwide isolation precautions to prevent the spread of COVID-19. Places where social interaction is widespread such as cafes, restaurants, gyms and courses were closed (Republic of Turkey, Ministry of Interior, 2020a). The older adults in Turkey were the first group who were encouraged to stay at home and were given more stringent directives in terms of social distancing (Republic of Turkey, Ministry of Interior, 2020b). Older adults were restricted from leaving their homes, staying in crowded environments and traveling by public transportation in order to protect them from the pandemic (Republic of Turkey, Ministry of Interior, 2020b). This global state of lockdown due to the COVID-19 outbreak resulted in individuals being exposed to an unprecedented stressful situation of unknown duration (Altena et al., 2020). Researchers have indicated that older adults who experience prolonged isolation may experience health effects that last longer than the time spent in quarantine (Marrow-Howell et al., 2020). However, the psychosocial problems that this situation may cause have not yet been fully determined (Morrow-Howell et al., 2020; Yang et al., 2020).

Factors such as social isolation, stress and changing lifestyle experienced by older adults during the COVID-19 outbreak can affect their mental state. (Jiménez-Pavón et al., 2020; Morrow-Howell et al., 2020). Mental health problems are known to increase susceptibility to infection (Coughlin, 2012). Studies conducted before the COVID-19 outbreak indicate that older adults are faced with mental health problems such as loneliness and hopelessness, as such, these negative outcomes are likely to be further exacerbated by mandated social isolation requirements (Akgül \& Yeşilyaprak, 2018; Aydın \& İşleyen, 2004). Although there are many studies investigating the psychological conditions of the uninfected general population who were isolated at home during the COVID-19 outbreak (Huang \& Zhao, 2020; Roy et al., 2020), studies of older adults, who are a vulnerable group, are quite limited. (Jiménez-Pavón et al., 2020; Morrow-Howell et al., 2020; Wand et al., 2020; Yang et al., 2020). In addition, studies examining the COVID-19 outbreak among older adults mostly focus on the clinical characteristics of infected people (Lian et al., 2020; Liu et al., 2020; Niu et al. Niu, Jia, et al., 2020, Niu, Tian, et al., 2020). For this reason, it is thought that there is a need for studies examining factors that affect the emotional or psychological state of uninfected older adults.

Hopelessness is among the most important mental health problems among older adults (Aydın \& İşleyen, 2004; Şahin, 2019). Hope is having positive expectations for the future. Hopelessness, on the other hand, emerges with symptoms such as uncertainty about the future caused by the loss of hope, aimlessness, a decrease in the will to live, pessimism and helplessness (Moore, 2005; Öz, 2010). Being hopeful facilitates the body's ability to fight against diseases and strengthens the immune system (Öz, 2010). However, studies among older adults in Turkey indicate that hopelessness levels range from above average to high relative to the general 
population (Aydın \& İşleyen, 2004; Şahin, 2019). Studies emphasize that high hope is associated with less anxiety, especially among older adults. (Koenig, 2018). In addition, it is reported in the literature that social support and spirituality are important concepts in increasing hope (Koening, 2020; Armitage \& Nellums, 2020). Therefore, it is thought that the level of hope is important in reducing the anxiety and stress among older adults.

Another important problem seen in old age is loneliness (Akgül \& Yeşilyaprak, 2018; Khorshid et al., 2004). Loneliness refers to the incompatibility between individuals' real social relationships. The individual may feel alone while he/she is with other people or he/she may not feel lonely when there is no one around him/her (Cacioppo et al., 2015). Social isolation is an objective separation as it expresses a physical separation from other people, while loneliness is a subjective feeling of distress caused by separation (Cacioppo et al., 2015; Fakoya et al., 2020). However, the compulsory isolation brought by the pandemic process may lead to a subjective loneliness by reducing the social ties that the individual prefers to have (Wand et al., 2020). It was indicated that the quarantine and social isolation process can increase the loneliness levels of older adults (Morlett Paredes et al., 2021; Wand et al., 2020). It was emphasized that studies were needed to determine and reduce the levels of loneliness experienced by older adults during the process of COVID-19 outbreak (Brooke \& Jackson, 2020; Morrow-Howell et al., 2020). It was emphasized that spiritual well-being was effective in coping with the problems of hopelessness and loneliness experienced by older adults (Bini'Matillah, 2018; Ekhtiary et al., 2018).

Koening (2020) suggested that the use of religious belief resources and spirituality may be important for older adults who are isolated at home in dealing with COVID-19 (Koening, 2020). It was stated that religious and spiritual practices can directly affect many biological systems, including the sympathetic nervous, endocrine and immune systems (Hill et al., 2017). Spirituality is an important resource for health and spiritual well-being. Spirituality is thought to be a way to support and encourage older adults (Koening, 2020).

When the literature is examined, it can be said that the studies on hopelessness (Ironson et al., 2015), loneliness (Campagne, 2019) and spirituality (Black \& Slavich, 2016; Hill et al., 2017) that can affect immunity of non-infected older adults are insufficient (Black \& Slavich, 2016; Campagne, 2019; Hill et al., 2017). Scientific studies that deal with these components together have not been reached. It is thought that this research will provide important data on the concepts that can affect the mental state of the older adults who are not infected with COVID-19, but who experience a radical change in the way of life with strict isolation methods and will be a guide for interventional studies to improve the mental state. The aim of this study is to examine the relationship between hopelessness, loneliness and spiritual well-being levels of older adults during the COVID-19 process, unlike other previous studies in the literature. 


\section{Research Questions}

1. There is a significant negative relationship between the spiritual well-being of older adults and their levels of loneliness,

2. There is a significant negative relationship between the spiritual well-being of older adults and their levels of hopelessness,

3. There is a significant positive relationship between the loneliness of older adults and their levels of hopelessness.

\section{Methodology}

This study used a cross-sectional research design and snowball sampling. Data collected between October 13 and November 13, 2020, with people over 65 years of age living in three different cities in the Eastern Anatolia region in Turkey. The study sample consisted of individuals with chronic diseases over the age of 65 who meet the criteria for inclusion between the specified dates.

The inclusion criteria for the present study are as follows: being 65 years or older, the absence of neurological disorders that prevent filling the research forms, not having a psychiatric diagnosis (depression, personality disorder, substance addiction, etc.), and having no communication problem and being open to cooperation.

\section{Collection of Data}

Older adults who live in three different city in the Eastern Anatolia region of Turkey and who filled the survey form online made up the universe of this study. The snowball sampling method was used, and 476 older adults participated in the study.

Participant Demographic Characteristics (Ağırman \& Gençer, 2017; Akyıl et al., 2018; Şahin \& Özçetin, 2020), Beck Hopelessness Scale (BHS), Loneliness Scale (UCLA-LS) and Spiritual Well-being Scale (FACIT-Sp) were used in data collection. The survey was launched on October 13 and data were collected until November 13, 2020.

\section{Instruments}

Participant Demographic Characteristics: The personal information form prepared by the researcher (including age, gender, education level, working status, occupation status, marital and economic status) consists of 7 questions in total. 


\section{Beck Hopelessness Scale (BHS)}

Beck Hopelessness Scale was developed by Beck et al. (1974). It was adapted to Turkish by Seber et al. (1993). Beck Hopelessness Scale is a scale that measures individuals' negative perspectives about the future. Scores that range from 0-3 are considered as normal range of hopelessness, 4-8 are mild hopelessness, 9-14 are moderate hopelessness, and $>15$ are considered as severe hopelessness. As the score obtained from the scale increases, the level of hopelessness of the individual increases. It consists of 20 items in total. Answers are given as "yes" and "no" to the questions. Eleven of these items (2, 4, 7, 9, 11, 12, 14, 16, 17, 18 and 20) are given 1 point for the option "yes", 9 of them $(1,3,5,6,8,10,13,15$ and 19) are given 1 point for the "no" option. The scale is evaluated over 20 points in total. BHS has 3 sub-dimensions. These are expectations about the future $(1,3,7,11,18)$, loss of motivation $(2,4,9,12,14,16,17,20)$ and hope $(5,6,8,10,13,15,19)$. Cronbach's alpha values of the Turkish adaptation of the BHS were found as 0.86 (Seber, 1991). In this study, however, the BHS Cronbach's alpha value was found to be 0.91 .

\section{UCLA-Loneliness Scale (UCLA-LS)}

It was developed by Russell et al. (1980). The Turkish form of the scale was adapted to Turkish in 1989 by Demir. The scale was developed to determine the general loneliness level of individuals. The total score for each individual is obtained by summing the scores obtained by the individuals from all items. The scale consists of one-dimensional 20 items such as "How often do you feel that you lack companionship?" and "How often do you feel that there is no one you can turn to?", etc. The higher the score is, the higher the level of loneliness is. The items containing positive statements $(1,5,6,9,10,15,16,19,20$. items) were scored as follows: never 4 , rarely 3 , sometimes 2 , often 1 point. On the contrary, the items containing negative expressions $(2,3,7,8,11,12,13,14,17,18$. items) were scored as follows: never 1 , rarely 2 , sometimes 3 , often 4 points. The scale is 4 -Likert type graded. The lowest score obtained from the scale is 20 and the highest score is 80 . The Cronbach's alpha coefficient of the scale is 0.96 , and it was found as 0.83 in this study.

\section{Spiritual Well-Being Scale (FACIT-Sp)}

This research utilized the Functional Assessment of Chronic Illness TherapySpiritual Well-Being Scale (FACIT-Sp). The Turkish form of the scale was adapted to Turkish in 2017 by Aktürk et al. It is a scale consisting of 12 items which evaluates spiritual well-being. The scale was originally developed with two components or factors and a total (overall) score: a four-item faith component and an eight-item meaning/peace component. More recent work isolated three components or factors: the four-item faith subscale and separate four-item subscales each for meaning and peace. Even more recent research has shed new light on the topic, demonstrating that the three-factor model yields a better fit (Bredle et al., 2011; Canada et al., 
2008; Haugan, 2015; Murphy et al., 2010; Whitford \& Olver, 2012). The scale has three sub-dimensions: meaning, peace and faith activities. The concept of spirituality is defined as an experience people have about meaning, peace and faith in life in the scale. For this reason, FACIT-Sp evaluates the concepts of finding a meaning in life, having a purpose in life, and feeling peaceful. The items in the scale are responded on a five-point Likert-type scale as "none" (0 point), "very little" (1 point), "a little" ( 2 points), "quite" (3 points) and "very much" (4 points). The higher the scale score, the better the spiritual well-being (Aktürk et al., 2017). In the present study, the Cronbach's Alpha internal consistency coefficient of FACIT-Sp was found to be 0.78 .

\section{Data Analysis}

Statistical Package for the Social Sciences 24 was used to analyze the data. Number, mean, percentage distributions and Pearson correlation analysis were used for these evaluations. All decisions on the statistical significance of the findings were made using a criterion alpha of 0.05 . While calculating the correlation strength in this study, the following ranges were taken as a reference: very weak correlation $(r=0-0.25)$, weak correlation $(r=0.26-0.49)$, moderate correlation $(r=0.50-0.69)$, strong correlation $(r=0.70-0.89)$ and very strong correlation $(r=0.90-1.0)$ (Gürbüz \& Şahin, 2014).

\section{Ethical Aspect of the Research}

Approval was obtained from ethics committee for the research (Number: E-10879717-050.01.04 11758). The individuals participating in the study were informed about the purpose of the research, the method, the time they would spend for the research that participating in the study would have posed minimal risk of harm and that the participation was completely voluntary, and their written consent was obtained.

\section{Results}

Characteristics of the participants included in the study are reported in (Table 1). The average age was $72.51 \pm 8.77$ years, $56.3 \%$ were female, $57.8 \%$ were literate, $54.6 \%$ were married, $62.6 \%$ of them were unemployed, $45.4 \%$ of them were homemaker, and $74.6 \%$ of them had moderate economic status (Table 1).

Older adults had $43.56(\mathrm{SD}=8.94)$ mean scores on loneliness. The mean scores of sub-dimension of hopelessness were $1.71(\mathrm{SD}=1.74)$ in emotions and expectations about the future, $3.48(\mathrm{SD}=2.35)$ in motivation loss, $2.96(\mathrm{SD}=2.30)$ in hope and $8.15(\mathrm{SD}=5.71)$ in total. The mean scores of spiritual well-being subscale were determined to be $8.40(\mathrm{SD}=2.40)$ in meaning subscale, $8.31(\mathrm{SD}=2.31)$ in peace subscale, $12.24(\mathrm{SD}=3.24)$ in belief subscale and $30.00(\mathrm{SD}=6.69)$ in total scores (Table 2). 
Table 1 Participant demographic characteristics

\begin{tabular}{|c|c|c|}
\hline \multirow{2}{*}{ Variables } & \multicolumn{2}{|l|}{$(n=476)$} \\
\hline & Number & $\%$ \\
\hline \multicolumn{3}{|l|}{ Age } \\
\hline $65-71$ & 249 & 52.3 \\
\hline $72-77$ & 107 & 22.5 \\
\hline 78 and above & 120 & 25.2 \\
\hline \multicolumn{3}{|l|}{ Gender } \\
\hline Female & 268 & 56.3 \\
\hline Male & 208 & 43.7 \\
\hline \multicolumn{3}{|l|}{ Education } \\
\hline Literate & 275 & 57.8 \\
\hline Primary school & 81 & 17.0 \\
\hline Secondary school & 67 & 14.1 \\
\hline High school and above & 53 & 11.1 \\
\hline \multicolumn{3}{|l|}{ Marital status } \\
\hline Married & 301 & 63.2 \\
\hline Single & 175 & 36.8 \\
\hline \multicolumn{3}{|l|}{ Working status } \\
\hline Yes & 178 & 37.4 \\
\hline No & 298 & 62.6 \\
\hline \multicolumn{3}{|l|}{ Occupation status } \\
\hline Retired & 181 & 38.0 \\
\hline Housewife & 216 & 45.4 \\
\hline Self-employed & 79 & 16.6 \\
\hline \multicolumn{3}{|l|}{ Economic status } \\
\hline Good & 76 & 16.0 \\
\hline Moderate & 355 & 74.5 \\
\hline $\mathrm{Bad}$ & 45 & 9.5 \\
\hline
\end{tabular}

When the relationship between loneliness, hopelessness and spiritual well-being scores of individuals over the age of 65 is examined (Table 3), it was determined that there was a moderately significant negative correlation between the loneliness $(r(476)=-0.604)$ and hopelessness $(r(476)=-0.641)$ total average scores and the spiritual well-being total average scores $(p<0.000)$. It was determined that there was a moderately significant positive correlation between the hopelessness total average scores and the loneliness total average scores of the participants $(r(476)=0.629$, $p<0.000$ ). In this study, it was found that as the spiritual well-being levels of individuals over 65 years of age increased, their loneliness $r(476)=-0.604$ and hopelessness $r(476)=-0.604$ levels decreased $(p<0.000)($ Table 3$)$. 
Table 2 Distribution of the lowest and highest scores and total average scores of older adults over the age of 65 on loneliness, hopelessness and spiritual well-being

\begin{tabular}{|c|c|c|c|c|}
\hline Scale & & Min & Max & Average score \\
\hline \multirow[t]{5}{*}{ Hopelessness } & Loneliness & 26.00 & 68.00 & $43.56 \pm 8.94$ \\
\hline & $\begin{array}{l}\text { Feelings and Expectations } \\
\text { for the Future }\end{array}$ & 0.00 & 5.00 & $1.71 \pm 1.74$ \\
\hline & Loss of Motivation & 0.00 & 8.00 & $3.48 \pm 2.35$ \\
\hline & Hope & 0.00 & 7.00 & $2.96 \pm 2.30$ \\
\hline & Total & 0.00 & 20.00 & $8.15 \pm 5.71$ \\
\hline \multirow[t]{4}{*}{ Spiritual well-being } & Meaning & 2.00 & 12.00 & $8.40 \pm 2.40$ \\
\hline & Peace & 2.00 & 14.00 & $8.31 \pm 2.31$ \\
\hline & Faith & 1.00 & 16.00 & $12.24 \pm 3.24$ \\
\hline & Total & 7.00 & 43.00 & $30.00 \pm 6.69$ \\
\hline
\end{tabular}

Table 3 Relationship between loneliness, hopelessness and spirituality average scores of older adults over the age of 65

\begin{tabular}{llcc}
\hline Scales & Spiritual well-being & Loneliness & Hopelessness \\
\hline Spiritual well-being & 1 & $\begin{array}{l}r=-.604^{*} \\
p=0.000\end{array}$ & $\begin{array}{l}r=-.641^{*} \\
p=0.000\end{array}$ \\
Loneliness & & 1 & $r=.629^{*}$ \\
& $r=-.604^{*}$ & & $p=0.000$ \\
Hopelessness & $p=0.000$ & $r=-.641^{*}$ & $r=.629^{*}$ \\
& & $p=0.000$ & $p=0.000$ \\
\hline
\end{tabular}

${ }^{*} p<0.01$ significant

\section{Discussion}

There is not enough information about the mental health problems experienced during COVID-19 outbreak by older adults, who are a vulnerable group (Morrow-Howell et al., 2020; Yang et al., 2020). It is thought that this research will provide information about the hopelessness, loneliness and spiritual well-being of older adults and will contribute to studies aimed at improving mental health. Findings obtained from the study were discussed in accordance with the relevant literature.

In this study, it was found that the hopelessness levels of the older adult population who were not infected during the outbreak period were below the middle level. Sarin et al. (2016) found in their study that the hopelessness level of older adults was moderate, Şahin et al. (2018), Choi et al. (2016) stated that older adults have high levels of hopelessness. The fact that this research was conducted during the COVID19 outbreak is thought to have an impact on the level of hope. It can be thought that the fact that most of the older adults spend their time with family members at home during the outbreak process reduces the level of hopelessness. In addition, it is reported that during the outbreak period, social ties strengthen and the tendency 
toward religion increases (Yağl1, 2020; Coyne et al., 2020; Koening, 2020). It can be said that these components, which are known to be effective on hope, are also effective in increasing hope.

In this study, it was determined that the loneliness level of older adults was below the middle level. In Turkey, older adults reported moderate levels of loneliness (Ünal \& Bilge, 2005; Aky1l et al., 2018; Kaçan et al., 2015). The studies conducted before the outbreak period and the findings obtained from this study differ. This situation shows that there is a decrease in the sense of loneliness experienced by older adults during the outbreak period. Tull et al. (2020) reported that spending time at home and perceived high social support during the COVID-19 process are associated with low loneliness. Losada-Baltar et al. (2021) emphasize that communicating with family members during the COVID-19 outbreak can reduce loneliness. These results are similar to our study. Palgi et al. (2020) stated that loneliness is the main risk factor for depression, anxiety and especially comorbid diseases. It is emphasized that older adults are more resistant to psychiatric disorders associated with the COVID19 outbreak. In addition, it is stated that adults over the age of 60 have more effective emotional regulation and more experience, and they experience less stress levels against life-threatening situations. Frenkel-Yosef et al. (2020) reported that a small number of face-to-face interactions and lack of regular activities in older adults will lead to an increase in loneliness. Luchetti et al. (2020) emphasize that older adults who live alone and have chronic diseases feel more alone. Morrow-Howell et al. (2020) emphasized that family and intergenerational relationships developed during the outbreak period and that the pandemic was effective in strengthening social ties (Morrow-Howell et al., 2020).

The spiritual well-being level of the older adults in the study was found to be above the middle level. In Turkey, in the studies conducted by Gürsu and Ay (2018), and Doğan (2018) with older adults, it was found that the spiritual well-being levels were above average levels. The results of this research are similar to previous studies. Koening (2020) stated that older adults may turn to religion and spirituality to alleviate the anxiety they experienced during the COVID-19 outbreak. They can use spirituality as a coping strategy (Hiçdurmaz \& Oz, 2013; Klavuz \& Klavuz, 2016). The outbreak process is thought to support the spiritual well-being of older adults.

In this study, it was determined that there is a positive significant relationship between hopelessness and loneliness. Zhang et al., and Niu et al. in their study with older adults, emphasized that there is a meaningful relationship between loneliness and hopelessness levels, and loneliness and hopelessness can be reduced by using social support systems (Niu et al. Niu, Jia, et al., 2020; Niu, Tian, et al., 2020; Zhang et al., 2017). These findings are similar to our study.

In this study, it was found that there is a significant relationship between hopelessness and spiritual well-being of older adults. Safitri et al. (2019), Hirakawa et al. (2019) found that hopelessness and spiritual well-being are related to different studies with older adults (Hirakawa et al., 2019; Safitri et al., 2019). Koenig stated that spirituality is a powerful source of hope and is effective in reducing despair (Koenig, 1994). Considering the negative effects of hopelessness on the immune system, it is thought that supporting older adults spiritually may reduce the long-term mental consequences of the COVID-19 outbreak (Şahin et al., 2018; Koening, 2020). 
In this study, a significant relationship was found between loneliness and spiritual well-being. In the study by Okamoto (2013) and Dashtbozorgi et al. (2016), it was stated that spirituality and loneliness were related (Okamoto, 2013; Dashtbozorgi et al. 2016). In another study, it was stated that spirituality significantly affects the reduction of loneliness and that increasing the level of spiritual well-being is an important factor that reduces loneliness (Turan \& Cekiç, 2018; Gallegos \& Segrin, 2019; Sadegh et al., 2018). Older adults realize that they are attached to a spiritual being or power and feel that they are not alone (Okamoto, 2013; Dashtbozorgi et al. 2016). It can be said that spirituality is effective in reducing the loneliness of older adults.

In the pandemic period, Turkey has implemented social isolation for the protection of older adults. Their daily living needs, home needs and medicines were taken to their homes. All needs of older adults at risk were met (Republic of Turkey, Ministry of Interior, 2020b). During the pandemic period, it is recommended that practices such as social policy practices and older adult service centers should be reorganized according to the scientific research results to meet current needs. It is thought that the data of the study will provide data to researches and social policy practices aimed at improving the mental health of older adults during the pandemic process.

In this study, it has been found that there is a significant relationship between the hopelessness, loneliness and spiritual well-being levels of older adults during the COVID-19 pandemic. It is thought that the data of the study will provide data for future research to improve the mental health of older adults during the outbreak process. In addition, it is thought that spiritual care will take a stronger place in the scope of gerontological social services in reducing the hopelessness and loneliness of older adults.

\section{Study Limitations}

FACIT-Sp was applied to assess the spiritual well-being of older adults participating in this study. FACIT-Sp is intertwined with concepts such as the purpose of life, meaning and feeling at peace. Significant differences can be seen among older adults in their perception of the purpose and meaning of life. Therefore, it may not be possible to generalize the results of the study to all older adults. In addition, since FACIT-Sp evaluates the concept of spirituality through positive mental states such as meaning in life, finding purpose and feeling peaceful, it is an expected result that the scale will be associated with positive emotions such as hope. This is one of the limitations of the study as it may cause bias in the research findings.

The data of this research was carried out through e-mails obtained from older adults living in three different cities. The fact that the researchers could not reach the older adults who cannot fill online questionnaires can be considered as the limitations of this study. Moreover, the researchers did not have information about whether any of the participants' relative was diagnosed with COVID-19 or died during this period can be considered as limitation of this study. 


\section{Conclusion}

In this study, it was found that during the COVID-19 outbreak, the hopelessness and loneliness levels of older adults were below the middle level, and their spiritual well-being levels were moderate. In addition, it was determined that there was a relationship between hopelessness, loneliness and spiritual well-being levels of older adults during the COVID-19 outbreak. As a result of this study, it is recommended to implement initiatives that increase hope, strengthen social ties and spiritual support for older adults during the COVID-19 outbreak. It might be beneficial for older adults who are in isolation during the pandemic period to receive quality health care services and increased telephone counseling practices might also help to prevent mental problems. Therapeutic practices can be offered online during the pandemic to improve mental health care. In addition, phone and video conference calls can be offered to individuals with the people they love and with voluntary institutions.

Acknowledgements The authors wish to thank and acknowledge the participants for sharing their experiences with us.

Author contribution MD contributed to the design, conducted the searches, screening and data extraction and contributed to the analysis and write-up of the manuscript. ZÖ conducted the searches and screening and contributed to write-up of the manuscript.

\section{Funding None.}

\section{Declarations}

Conflict of interest The authors declare that they have no conflict of interest in this study.

Ethical standard Approval was obtained from Muş Alparslan University Scientific Research and Publication Ethics Committee for the research (number: E-10879717-050.01.04 11758). Verbal consent to participate in the research was obtained from the individuals by giving information about the purpose of the research, the method, the time they would spare for the research, and by declaring that participating in the research would not do any harm and that the participation was completely voluntary.

\section{References}

A ̆̆ırman, E., \& Gençer, M. Z. (2017). Huzurevinde, evde ailesiyle ve yalnız yaşayan yaşlı bireylerde depresyon, yalnızlık hissi düzeylerinin karşılaştırılması. Çă̆daş Tıp Dergisi, 7(3), 234-240. https:// doi.org/10.16899/gopctd.349938.

Akgül, H., \& Yeşilyaprak, B. (2018). The effect of psychoeducation program for reducing lonelinesson loneliness level of the elderly. OPUS International Journal of Society Researches. 8(14):11-52. https://doi.org/10.26466/opus.401331.

Aktürk, Ü., Erci, B., \& Araz, M. (2017). Functional evaluation of treatment of chronic disease: Validity and reliability of the Turkish version of the Spiritual Well-Being Scale. Palliative \& Supportive Care, 15(6), 684. https://doi.org/10.1017/S1478951517000013.

Akyıl, R. Ç., Adıbelli, D., Erdem, N., Kırağ, N., Aktaş, B., \& Karadakovan, A. (2018). Relationship of the level of loneliness and perceived social support and happiness in elders staying at home and nursing home. Anatolian Journal of Nursing and Health Sciences. 21(1):33-41. https://dergi park.org.tr/en/pub/ataunihem/issue/36782/369204. 
Alejandra, M. P., Ellen, E. L., Lisa, C., Saumya, G., Barton, W. P., Lawrence, A. P. H. C. K., \& Dilip, V. J. (2020). Qualitative study of loneliness in a senior housing community: The importance of wisdom and other coping strategies. Aging and Mental Health, 10, 1-8. https://doi.org/10.1080/ 13607863.2019.1699022

Altena, E., Baglioni, C., Espie, C. A., Ellis, J., Gavriloff, D., Holzinger, B., \& Riemann, D. (2020). Dealing with sleep problems during home confinement due to the COVID-19 outbreak: Practical recommendations from a task force of the European CBT-I Academy. Journal of Sleep Research., 29, e13052. https://doi.org/10.1111/jsr.13052

Armitage, R., \& Nellums, L. B. (2020). Covid-19 and the consequences of isolating the elderly. The Lancet Public Health, 5(5), e256. https://doi.org/10.1016/S2468-2667(20)30061-X

Aydın, İ., \& İşleyen, S. (2004). The effects of future expectations of the elderly living in nursing home on their hopelessness. Anatolian Journal of Nursing and Health Sciences, 7(3), 19-25. https:// dergipark.org.tr/en/download/article-file/29238.

Beck, A. T., Weissman, A., Lester, D., \& Trexler, L. (1974). The measurement of pessimism: The hopelessness scale. Journal of Consulting and Clinical Psychology, 42, 861-865. https://psycnet.apa.org/ record/1975-09735-001

Bini'Matillah, U., Susumaningrum, L. A., \& Ala, M. Z. (2018). Correlation between spirituality and loneliness in elderly in the UPT Pelayanan Sosial Tresna Werdha. Pustaka Kesehatan. 6(3), 438445. https://jurnal.unej.ac.id/index.php/JPK/article/view/11589.

Black, D. S., \& Slavich, G. M. (2016). Mindfulness meditation and the immune system: A systematic review of randomized controlled trials. Annals of the New York Academy of Sciences, 1373(1), 13-24. https://doi.org/10.1111/nyas. 12998

Bredle, J. M., Salsman, J. M., Debb, S. M., et al. (2011). Spiritual well-being as a component of health-related quality of life: The functional assessment of chronic illness therapy-spiritual wellbeing scale (FACIT-Sp). Religions, 2(1), 77-94.

Brooke, J., \& Jackson, D. (2020). Older people and COVID-19: Isolation, risk and ageism. Journal of Clinical Nursing., 29, 2044-2046. https://doi.org/10.1111/jocn.15274

Cacioppo, S., Grippo, A. J., London, S., Goossens, L., \& Cacioppo, J. T. (2015). Loneliness: Clinical import and interventions. Perspectives on Psychological Science, 10(2), 238-249. https://doi. org/10.1177/1745691615570616

Campagne, D. M. (2019). Stress and perceived social isolation (loneliness). Archives of Gerontologyand Geriatrics, 82, 192-199. https://doi.org/10.1016/j.archger.2019.02.007

Canada, A. L., Murphy, P. E., Fitchett, G., et al. (2008). A 3-actor model for the FACIT-Sp. PsychoOncology., 17(9), 908-916.

Choi, Y. S., Lee, J. H., Seo, A. R., \& Park, K. S. (2016). The association between hopelessness, social support and community integration and depression among elderly living alone. Journal of Agricultural Medicine and Community Health., 41(4), 195-204. https://doi.org/10.5393/JAMCH. 2016.41.4.195

Coughlin, S. (2012). Anxiety and depression: Linkages with viral diseases. Public Health Reviews, 34(2), 1-17. https://doi.org/10.1007/BF03391675.pdf.

Coyne, L. W., Gould, E. R., Grimaldi, M., Wilson, K. G., Baffuto, G., \& Biglan, A. (2020). First things first: parent psychological flexibility and self-compassion during COVID-19. Behavior Analysis in Practice, 1-7. https://doi.org/10.1007/s40617-020-00435-w.

Dashtbozorgi, Z., Sevari, K., \& Safarzadeh, S. (2016). Effectiveness of Islamic spiritual therapy on the feeling of loneliness and death anxiety in elderly people. Journal of Aging Psychology.2(3):177-186. https://jap.razi.ac.ir/m/article_616.html?lang=en.

Demir, A. (1989). Validity and reliability of UCLA loneliness scale. Psychology Journal, 7(23), 14-18. https://open.metu.edu.tr/handle/11511/81352.

Doğan, S. (2018). Spiritual care, quality of life and evaluation of relationship in elderly individuals without chronic diseases (Master's thesis, Kafkas University) Kars. https://tez.yok.gov.tr/Ulusa 1TezMerkezi.

Ekhtiary, S. M., Imani, N. M., \& MirzaMohammadi, M. H. (2018). The prediction of loneliness among the kermanshahi elderly based on self-compassion, spirituality, and islamic lifestyle. Journal of Religion and Health, 4(2), 69-80. https://www.sid.ir/en/Journal/ViewPaper.aspx?ID= 594951.

Fakoya, O. A., McCorry, N. K., \& Donnelly, M. (2020). Loneliness and social isolation interventions for older adults: A scoping review of reviews. BMC Public Health, 20(1), 1-14. https://doi.org/ 10.1186/s12889-020-8251-6 
Frenkel-Yosef, M., Maytles, R., \& Shrira, A. (2020). Loneliness and its concomitants among older adults during the COVID-19 pandemic. International Psychogeriatrics., 32(10), 1257-1259. https://doi. org/10.1017/S1041610220003476)

Gallegos, M. L., \& Segrin, C. (2019). Exploring the mediating role of loneliness in the relationship between spirituality and health: Implications for the Latino health paradox. Psychology of Religion and Spirituality., 11(3), 308. https://doi.org/10.1037/re10000180

Gürbüz, S., \& Şahin, F. (2014). Sosyal bilimlerde araştırma yöntemleri. Seçkin Yayıncılık.

Gürsu, O., \& Ay, Y. (2018). Religion, spiritual well-being and old age. Journal of International Social Research, 11(61). https://doi.org/10.17719/jisr.2018.3007.

Haugan, G. (2015). The FACIT-Sp spiritual well-being scale: An investigation of the dimensionality, reliability and construct validity in a cognitively intact nursing home population. Scandinavian Journal of Caring Sciences., 29, 152-164.

Hiçdurmaz, D, \& Oz, F. (2013). Spirituality as a dimension of coping. Anatolian Journal of Nursing and Health Sciences, 16(1), 50-6. https://dergipark.org.tr/tr/pub/ataunihem/issue/2660.

Hill, T. D., Rote, S. M., \& Ellison, C. G. (2017). Religious participation and biological functioning in Mexico. Journal of Aging and Health., 29, 951-972. https://doi.org/10.1177/0898264317716244

Hirakawa, Y., Chiang, C., Yasuda, K., Iwaki, Y., Andoh, H., \& Aoyama, A. (2019). Spirituality in older men living alone near the end-of-life. Nagoya Journal of Medical Science. 81(4), 557.https://doi. org/10.18999/nagjms.81.4.557.

Huang, Y., \& Zhao, N. (2020). Generalized anxiety disorder, depressive symptoms and sleep quality during COVID-19 outbreak in China: A web-based cross-sectional survey. Psychiatry Research., 288, 112954. https://doi.org/10.1016/j.psychres.2020.112954

Ironson, G., O’Cleirigh, C., Kumar, M., Kaplan, L., Balbin, E., Kelsch, C.B., Fletcher, M.A., \& Schneiderman, N.(2015). Psychosocial and neurohormonal predictors of HIV disease progression (CD4 cells and viral load): a 4-year prospective study. AIDS Behaviour, 19, 1388-1397. https://doi.org/10. 1007/s10461-014-0877-x

Jiménez-Pavón, D., Carbonell-Baeza, A., \& Lavie, C. J. (2020). Physical exercise as therapy to fight against the mental and physical consequences of COVID-19 quarantine: Special focus in older people. Progress in Cardiovascular Diseases, 63(3), 386-388. https://doi.org/10.1016/j.pcad.2020.03. 009

Kaçan, S.H., Öztürk, A., Dindaş, İ., \& Göçmen, M. (2015). Kastamonu 1no'lu aile sağlığı merkezine başvuranyaşlıların yalnızlık düzeyini etkileyen bazı faktörlerin incelenmesi. Yaşlı Sorunları Araştırma Dergisi, 2, 88-97. https://acikerisim.bartin.edu.tr/handle/11772/1217

Khorshid, L., Eşer, İ., Zaybak, A., Yapucu, Ü., Arslan, G., \& Çınar, Ş. (2004). The evaluation of loneliness level of elderly individuals residing in rest homes. Turkish Journal of Geriatrics, 7(1), 45-50. https://dergipark.org.tr/tr/pub/tjfmpc/issue/29637/317717.

Klavuz, M. A., \& Klavuz, E. (2016). Yaşlanma döneminde kayıplarla başa çıkmada manevi danışmanlık hizmetlerinin önemi. In Ayten, A., Koç, M., \& Tınaz, N. (Eds.), Manevi Danışmanlık ve Rehberlik Dem Yayınlarl (pp. 17-38).

Koenig, H. (1994). Religion and hope; religion in aging and health: Theoretical Foundations and Methodological Frontiers, 18-51.

Koenig, H. G. (2020). Ways of protecting religious older adults from the consequences of COVID19. The American Journal of Geriatric Psychiatry.(pp.1-8). https://doi.org/10.1016/j.jagp.2020.04. 004

Koenig, H. G. (2018). Religion and mental health: Research and clinical applications (pp. 4-16). Academic Press, Elsevier.

Lian, J., Jin, X., Hao, S., Cai, H., Zhang, S., Zheng, L., \& Zhang, X. (2020). Analysis of epidemiological and clinical features in older patients with coronavirus disease 2019 (COVID-19) outside Wuhan. Clinical Infectious Diseases, 71(15), 740-747. https://doi.org/10.1093/cid/ciaa242

Liu, K., Chen, Y., Lin, R., \& Han, K. (2020). Clinical features of COVID-19 in elderly patients: A comparison with young and middle-aged patients. Journal of Infection, 80(6), 14-18. https://doi.org/10. 1016/j.jinf.2020.03.005

Losada-Baltar, A., Jiménez-Gonzalo, L., Gallego-Alberto, L., del Sequeros Pedroso-Chaparro, M., Fernandes-Pires, J., \& Márquez-González, M. (2021). "We are staying at home." Association of self-perceptions of aging, personal and family resources, and loneliness with psychological distress during the lock-down period of COVID-19. The Journals of Gerontology: Series B, 76(2), 10-16. https://doi.org/10.1093/geronb/gbaa048. 
Luchetti, M., Lee, J. H., Aschwanden, D., Sesker, A., Strickhouser, J. E., Terracciano, A., \& Sutin, A. R. (2020). The trajectory of loneliness in response to COVID-19. American Psychologist, 75(7), 897-908. https://doi.org/10.1037/amp0000690

Moore, S. L. (2005). Hope makes a difference. Journal of Psychiatric and Mental Health Nursing, 12(1), 100-105. https://doi.org/10.1111/j.1365-2850.2004.00802.x

Morlett Paredes, A., Lee, E. E., Chik, L., Gupta, S., Palmer, B. W., Palinkas, L. A., \& Jeste, D. V. (2021). Qualitative study of loneliness in a senior housing community: The importance of wisdom and other coping strategies. Aging \&amp; Mental Health., 25(3), 559-566. https://doi.org/10.1080/13607863. 2019.1699022

Morrow-Howell, N., Galucia, N., \& Swinford, E. (2020). Recovering from the COVID-19 pandemic: A focus on older adults. Journal of Aging \&amp; Social Policy., 32(4), 526-535. https://doi.org/10. 1080/08959420.2020.1759758

Murphy, P. E., Canada, A. L., Fitchett, G., et al. (2010). An examination of the 3-factor model and structural invariance across racial/ethnic groups for the FACIT-Sp: A report from the American Cancer Society's Study of Cancer Survivors-II (SCS-II). Psycho-Oncology, 19(3), 264-272.

Niu, L., Jia, C., Ma, Z., Wang, G., Sun, B., Zhang, D., \& Zhou, L. (2020). Loneliness, hopelessness and suicide in later life: A case-control psychological autopsy study in rural China. Epidemiology and Psychiatric Sciences, 29(E119), 1-7. https://doi.org/10.1017/S2045796020000335

Niu, S., Tian, S., Lou, J., Kang, X., Zhang, L., Lian, H., \& Zhang, J. (2020). Clinical characteristics of older patients infected with COVID-19: A descriptive study. Archives of Gerontology and Geriatrics., 89, 104058. https://doi.org/10.1016/j.archger.2020.104058

Okamoto, N. (2013). The concept of spiritual well-being in the elderly and its characteristics (in Japanese). Kawasaki Journal of Medical Welfare, 23, 37-48.

Öz, F. (2010). Basic concepts in health (2nd edn, pp. 37-46). Mattek Matbaacılık Bas. Yay. Tic. Ltd. Şti. Ankara.

Palgi, Y., Shrira, A., Ring, L., Bodner, E., Avidor, S., Bergman, Y., Cohen-Fridel, S., Keisari, S., \& Hoffman, Y. (2020). The loneliness pandemic: Loneliness and other concomitants of depression, anxiety and their comorbidity during the COVID-19 outbreak. Journal of Affective Disorders., 275, 109111. https://doi.org/10.1016/j.jad.2020.06.036

Republic of Turkey, Ministry of Interior. (2020b). 65 yaş ve üstü ile kronik rahatsızlığı olanlara sokağa çıkma yasağı genelgesi. https://www.icisleri.gov.tr/65-yas-ve-ustu-ile-kronik-rahatsizligi-olanlarasokaga-cikma-yasagi-genelgesi.

Republic of Turkey, Ministry of Interior. (2020a). Koronavirüs salgını ile mücadele kapsamında kafeler/ lokantalar ile ilgili ek genelge. https://www.icisleri.gov.tr/koronavirus-salgini-ile-mucadele-kapsa minda-lokantalarla-ilgili-ek-genelge.

Roy, D., Tripathy, S., \& Kar, S. K. (2020). Study of knowledge, attitude, anxiety \& perceived mental healthcare need in Indian population during COVID-19 pandemic. Asian Journal of Psychiatry., 51, 102083. https://doi.org/10.1016/j.ajp.2020.102083

Russell, D., Peplau, L. A., \& Cutrona, C. E. (1980). The revised UCLA loneliness scale: Concurrent and discriminant validity evidence. Journal of Personality and Social Psychology., 39(3), 472. https:// doi.org/10.1037/0022-3514.39.3.472

Sadegh, M. E., Naeini, M. I., \& MirzaMohammadi, M. H. (2018). The prediction of loneliness among the kermanshahi elderly based on self-compassion, spirituality, and Islamic lifestyle. People. Journal of Research in Religious Health, 4(2), 69-80. https://www.sid.ir/en/Journal/ViewPaper.aspx?ID= 594951.

Safitri, W., Sugiharto, D. Y. P., \& Sutoyo, A. (2019). Spiritual well being in the elderly. Jurnal Bimbingan Konseling, 8(3), 86-91. https://doi.org/10.15294/jubk.v9i1.29127.

Şahin, M. A. (2019). The effect of social support perception on loneliness and hopelessness in elderly individuals. Institute of Health Sciences (Master thesis, Erzıncan University). Erzıncan. http://earsiv.erzincan.edu.tr/xmlui/handle/20.500.12432/2083.

Şahin, N. E., \& Özçetin, Y. S. Ü. (2020). Huzurevinde yaşayan yaşlı bireylerin yaşam doyumu ve umutsuzluk düzeyi. Mersin Üniversitesi Sağllk Bilimleri Dergisi, 13(2), 167-176. https://doi.org/10.26559/ mersinsbd.674370.

Şahin, E., Topkaya, N., Gençoğlu, C., \& Ersanlı, E. (2018). Prevalence and correlates of hopelessness among Turkish elderly people living with family or in nursing homes. Societies, $8(2)$, 39. https://doi. org/10.3390/soc 8020039 
Sarin, K., Punyaapriya, P., Sethi, S., \& Nagar, I. (2016). Depression and hopelessness in institutionalized elderly: A societal concern. Open Journal of Depression, 5(03), 21. https://doi.org/10.4236/ojd. 2016.53003

Seber, G., Dilbaz, N., Kaptanoğlu, C., \& Tekin, D. (1993). Hopelessness scale: Its validity and reliability. Kriz Journal, 1(3), 139-142. https://dergipark.org.tr/tr/pub/kriz/issue/41113/496925.

Sheikholeslami, F., Masole, S. R., Rafati, P., Esmaeili Vardanjani, S. A., Yazdani Talami, M. A, \& Khodadadi, N. (2012). The relationship between the religious beliefs and the feeling of loneliness in elderly. Indian Journal of Science and Technology, 5(3), 2411-2416. http://eprints.skums.ac.ir/ $3052 \%$.

Softa, H. K., Öztürk, A., Dindaş, İ., \& Göçmen, M. (2015). A study of the factors affecting the level of loneliness in the elderly people having applied to Kastamonu Family Health Center Nr. 1. Elderly Issues Research Journal, 2, 88-97. https://dergipark.org.tr/en/pub/yasad/issue/21801/234275.

Tull, M. T., Edmonds, K. A., Scamaldo, K. M., Richmond, J. R., Rose, J. P., \& Gratz, K. L. (2020). Psychological outcomes associated with stay-at-home orders and the perceived impact of COVID-19 on daily life. Psychiatry Research., 289, 113098. https://doi.org/10.1016/j.psychres.2020.113098

Turan, Y., \& Cekic, A. (2018). Coping with loneliness: Loneliness, religious coping, religiosity, life satisfaction and social media usage. Cumhuriyet Theology Journal, 22(3), 1711-45. https://www.ceeol. $\mathrm{com} / \mathrm{search} /$ article-detail?id=674096.

Ünal, G., \& Bilge, A. (2005). Investigation of loneliness, depression and cognitive functions in the advanced age group. Turkish Journal of Geriatrics, 8(2), 89-93. https://app.trdizin.gov.tr/publication/paper/detail/TIRZeE1qQXc.

Wand, A. P. F., Zhong, B. L., Chiu, H. F. K., Draper, B., \& De Leo, D. (2020). Covid-19: The implications for suicide in older adults. International Psychogeriatrics., 32(10), 1225-1230. https://doi.org/ $10.1017 /$ S 1041610220000770

Whitford, H. S., \& Olver, I. N. (2012). The multidimensionality of spiritual wellbeing: Peace, meaning, and faith and their association with quality of life and coping in oncology. Psycho-Oncology., 21(6), $602-510$.

World Health Organisation. (2020, October 20). Coronavirus disease (COVID-19) technical guidance. https://www.who.int/emergencies/diseases/novel-coronavirus-2019/technical-guidance

Yağl1, N. (2020). A psychosocial evaluation on the relationship between grief and religion during the pandemic period of covid-19. Turkish Studies, 15(6), 925-947. https://doi.org/10.7827/TurkishStu dies. 45119

Yang, Y., Li, W., Zhang, Q., Zhang, L., Cheung, T., \& Xiang, Y. T. (2020). Mental health services for older adults in China during the COVID-19 outbreak. The Lancet Psychiatry, 7(4), 9. https://doi. org/10.1016/S2215-0366(20)30079-1

Zhang, D., Yang, Y., Sun, Y., Wu, M., Xie, H., Wang, K., \& Su, Y. (2017). Characteristics of the Chinese rural elderly living in nursing homes who have suicidal ideation: A multiple regressionmodel. Geriatricnursing, 38(5), 423-430. https://doi.org/10.1016/j.gerinurse.2017.02.005

Publisher's Note Springer Nature remains neutral with regard to jurisdictional claims in published maps and institutional affiliations. 